\title{
Coastal Wetlands and Global Change: Overview
}

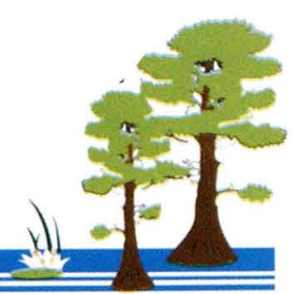

$\mathbf{T}$

he potential impacts of climate change are of great practical concern to those interested in coastal wetland resources. Among the areas of greatest risk in the United States are low-lying coastal habitats with easily eroded substrates which occur along the northern Gulf of Mexico and southeast Atlantic coasts. The Intergovernmental Panel on Climate Change (IPCC) and the World Meteorological Organization (WMO) have identified coastal wetlands as ecosystems most vulnerable to direct, large-scale impacts of climate change, primarily because of their sensitivity to increases in sea-level rise.

Global sea level has risen between 10 and $25 \mathrm{~cm}$ over the past 100 years. The IPCC (1995) expects average sea level will continue to increase as a result of thermal expansion and melting of glaciers and ice sheets. Models using the IPCC's current "best estimate" values of climate sensitivity and ice melt suggest an increase in sea level of about $50 \mathrm{~cm}$ from the present to 2100 . Continued rise in sea level will increase the depth of coastal waters and will cause inland and upstream salinity intrusion, both of which will affect fresh and brackishwater wetlands. While there is uncertainty regarding the influence of global warming on the frequency and intensity of storm events, sea-level rise alone has the potential for increasing the severity of storm surge, particularly in areas where coastal habitats and barrier shorelines are rapidly deteriorating. These direct consequences of global change increase the vulnerability of coastal wetlands (including mangroves and salt marshes) which are already heavily impacted by human activities.

Continued loss of coastal wetlands has tremendous economic and biological consequences. These areas provide essential habitat for many endangered and threatened species as well as many commercially important and recreational fisheries. Coastal areas of Louisiana alone provide the natural resource base for a $\$ 1$-billionper-year fish and shellfish industry.

\section{Threatened Habitats}

Coastal wetlands will be affected by large-scale climatic shifts. For example, rates of subsidence (the sinking of land below sea level) and sea-level rise (or "eustacy," caused by thermal expansion of water and melting of polar ice caps and glaciers) are not being balanced by accretion (sediment accumulation) in many gulf coast wetlands, resulting in increased flooding, saltwater intrusion into freshwater wetlands, and erosion of the coastline (Fig. 1). Although many coastal wetlands have maintained their relative elevation in response to gradual increases of 1-2 mm/yr in sealevel rise over the last several hundred years, these rates are projected to increase two- to fourfold within the next century.

Global change models predict a $1^{\circ}$ to $3.5^{\circ} \mathrm{C}$ increase in global mean temperature by 2100 but knowledge is insufficient to reliably model changes in regional precipitation patterns (IPCC, 1995). Variations in patterns of precipitation and temperature can affect the growth of individual trees, tree species population dynamics, ecosystem structure, and the geographic distribution of low-lying forests and forest communities.

Underlying the predicted climatic changes is an overall increase in carbon dioxide concentrations in the

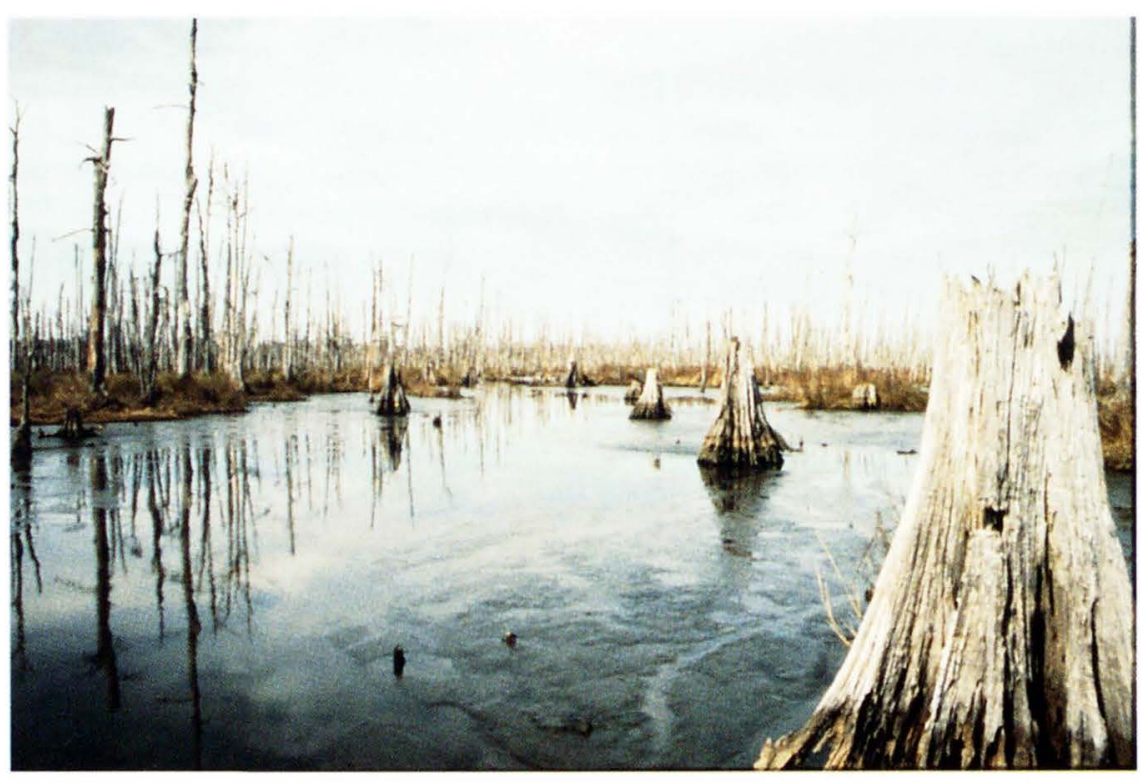

Fig. 1. "Ghost swamps" result when saltwater floods baldcypress swamps. 
atmosphere. Increased atmospheric carbon dioxide concentrations should also result in an increase in dissolved inorganic carbon concentrations in coastal waters. Such a change may affect the submerged aquatic plant communities.

\section{Goals}

The coastal wetland global change research program seeks to 1) identify sensitive ecosystems and critical processes, 2) understand the current condition of these ecosystems, 3 ) develop predictive tools which model the vulnerability of habitats to environmental changes, and 4) develop management recommendations to ameliorate the potential impacts. This work has concentrated on land managed by the Department of the Interior (Fig. 2). Climate change is projected to have significant regional impacts on resource management and use of these public lands. Southeastern coastal wetlands are also high priority areas for state fish and wildlife agencies because of the renewable resource base associated with these habitats.

\section{Coastal Marshes}

Over the past few decades, the rate at which coastal wetlands have been lost world-wide has averaged 0.5 $1.5 \%$ per year. In many coastal wetlands, the level of the marsh surface does keep pace with the current global average sea-level rise of

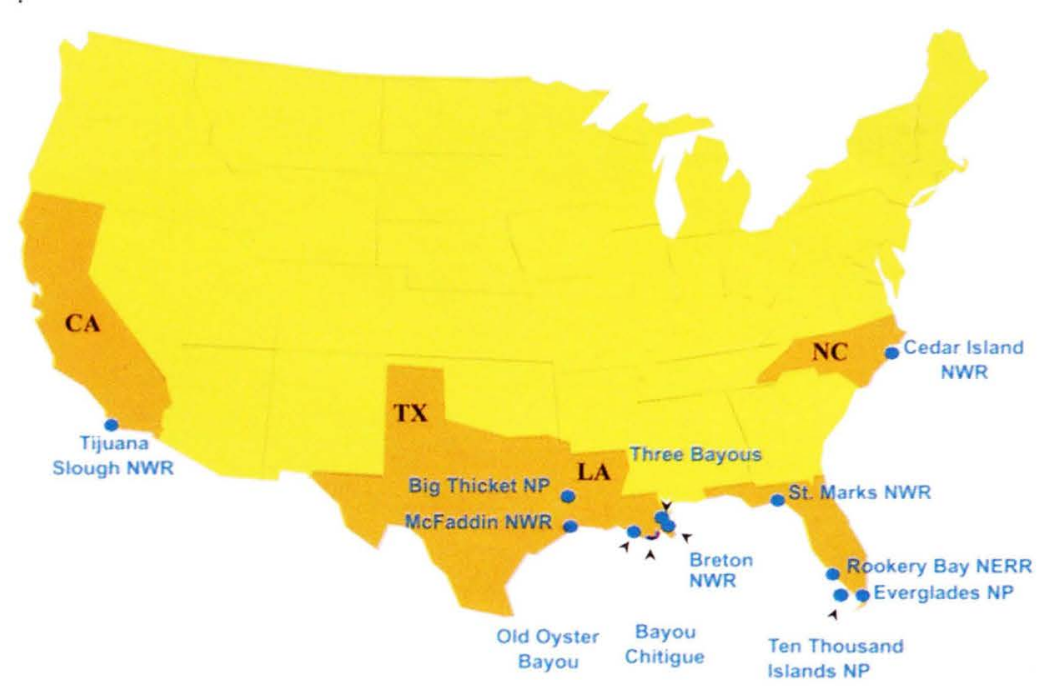

Fig. 2. Study sites for the coastal marsh research.
1-2 mm/yr. However, areas in south Louisiana with high local rates of soil subsidence are experiencing relative sea-level rise rates up to 10 times the global mean sea-level rise. Localized soil compaction, impacts from human activities, sea-level rise, and other factors have contributed to rates of coastal wetland loss in south Louisiana exceeding $65 \mathrm{~km}^{2} / \mathrm{yr}$.

U.S. Geological Survey (USGS) scientists and their collaborators have evaluated the potential for the submergence and subsequent loss of a range of wetlands along the coast of the United States. Marsh submergence can only be prevented if sediment accumulation and organic matter production and accumulation by plants result in a vertical buildup of the marsh so surface elevation keeps pace with or exceeds the rate of relative sea-level rise.

Surface elevation changes lagged behind sediment deposition at 7 of the 12 coastal wetlands studied. Four sites with significant soil subsidence and lower surface elevations relative to sea level had high rates of sediment accumulation. This inverse relationship suggests that physical and biological processes occurring in the top few meters of the soil are as or more important than sediment accumulation in determining soil surface elevation (Fig. 3). It is likely that estimates of marsh loss based only on tide gauge records and rates of

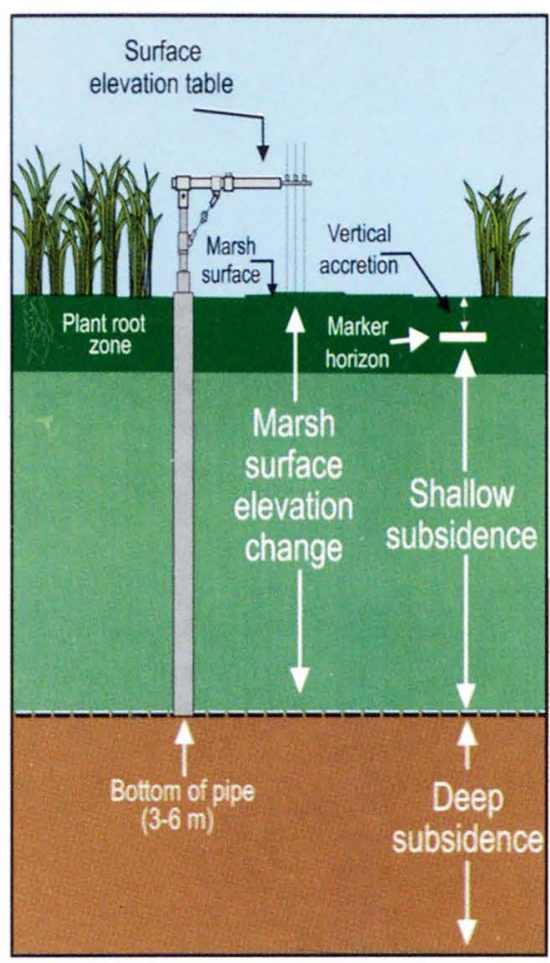

Fig. 3. Method used to measure marsh elevation change and shallow subsidence.

sediment accumulation underestimate the actual rates of coastal wetland submergence.

As sea level rises, coastal marshes can also persist by extending inland and occupying formerly upland sites. As lower elevation sites become submerged, marsh build-up and expansion may occur up the slope of the landward marsh boundary. This horizontal migration can be impeded if the slope of the surface is too steep or if barriers to new marsh formation exist, such as sea walls, roads, or buildings.

Duke University and USGS scientists recently modeled the movement of the marsh edge in North Carolina's Pamlico Sound. Field data indicate that movement of the marsh edge occurs in a series of discrete events. These events are separated by longer periods of relatively little marsh movement. Inland movement of the marsh is associated with disturbance of the upland vegetation from major storms or fire. The general model implies that upslope marsh movement is controlled not only by sea-level rise but also by local conditions. 


\section{Submerged Aquatic Plants}

Communities of submerged aquatic vegetation found in marine, estuarine, and coastal freshwater environments provide critical habitat for fish, shrimp, wintering waterfowl, and endangered species such as sea turtles and manatees, as well as improve water quality and provide erosion protection. Field and laboratory experiments addressed the response of submerged plant species to elevated dissolved inorganic carbon concentrations in the water column, sea-level rise/salinity intrusion, and physical disturbance by storms.

The photosynthetic activity of three freshwater submerged aquatic plant species-wild-celery, coontail, and hydrilla - as well as a seagrass species, shoalgrass, exposed to higher concentrations of dissolved carbon dioxide were measured in the laboratory. All four species showed an increase in photosynthetic activity in response to higher carbon dioxide concentrations. The results of experiments with shoalgrass are particularly significant because seagrass photosynthesis was not thought to be limited by dissolved inorganic carbon concentrations.

Longer term growth experiments were conducted with wild-celery and shoalgrass grown in laboratory mesocosms aerated with carbon dioxide-enriched air. Both species exhibited changes in biomass allocation and an increased ratio of carbon to nitrogen in certain plant tissues but did not respond with increased growth. Higher ratios of carbon to nitrogen in plant tissue tend to provide poorer quality forage for wintering waterfowl that rely on aquatic plant species for their food supply. Increased epiphytic growth occurred on shoalgrass and resulted in a decline in its dominance because of shading by the epiphytes (plants which depend upon other plants for structural support).

We can associate general groups of submerged aquatic vegetation species with broad salinity zones. But as sea level continues to rise, salt water will move farther inland, subjecting fresh and brackish marsh communities to salinity stress. Experiments in a greenhouse showed that species known to be strong competitors for light and nutrients dominated at low salinities but did not grow well at higher salinities because of a physiological intolerance to high salinity. Species tolerant of high salinities proved to be weak competitors at low salinities. At moderate to high salinities community structure was determined by the salinity tolerance of the species. Results indicate that salt tolerant species including wild-celery, widgeon grass, and sago pondweed will dominate those areas where saltwater intrusion results in habitat with higher salinities. An increase in the severity of tropical storms associated with climate change can also have acute impacts on seagrass communities.

Turtlegrass was found in protected areas of Chandeleur Sound located off coastal Louisiana which are characterized by nutrient rich sediments of high organic content and low sand content. Manatee grass occurred in patches characterized by sandy sediments. An increase in the deposition of sandy beach and offshore sediments in seagrass beds is expected to cause shifts in community structure by promoting an increase of manatee grass.

\section{Coastal Forested Wetlands}

Forested wetlands at low elevations are already threatened by logging and alterations in hydrology. USGS scientists and their collaborators examined the effects of potential increases in flood duration and salinity level through a series of growth and physiological experiments on 10 major wetland tree and shrub species.

Physiological measures can be good predictors of whole-plant growth responses that may not be evident for years or decades. In greenhouse experiments, baldcypress was relatively tolerant to permanent flooding but relatively intolerant to exposure to saline waters. Oaks, which usually occur on ridges no more than $30-60 \mathrm{~cm}$ above the surrounding swamps, were vulnerable to a combination of flooding and salinity stress. Chinese tallowtree, a highly invasive exotic species, was tolerant to the combined salinity and flooding stresses associated with simulated storm surges. Flooding was more important than small increases in salinity in the growth and survival of most tree species tested, whereas chronic or large increases in salinity were very harmful to all of the species tested regardless of flooding regime.

Large-scale shifts and/or losses in wetland forest communities are likely to occur over the next 50 years due to salinity increases if current trends in sea-level rise continue. However, considerable variation in salt tolerance existed among natural populations of baldcypress. Greenhouse and field experiments demonstrated that this tolerance has a genetic component and is inheritable. These findings imply that new varieties of baldcypress can be developed and used in reforestation efforts where existing populations have been killed by saltwater intrusion.

Long-term monitoring at Big Thicket National Preserve in southeast Texas is helping us understand coastal forest response to climate change. Permanent study plots help quantify the dynamics of forest structure and response to changes in climate. Resulting data suggest that increases in drought associated with changing climate may significantly alter understory seedling populations in bottomland forests and recruitment into the sapling layers, and ultimately influence overstory canopy structure

Increased disturbance associated with flooding and storms may favor early successional, shade-intolerant species at the expense of shadetolerant species. Perhaps more importantly, increased disruptions to the forest canopy will provide recruitment opportunities for exotic woody species, enhancing their rate of invasion into natural stands. The costs to control exotic species will continue to rise in national parks and other managed natural areas.

Landscape simulation models confirmed that hurricane disturbance also plays a major role in the structural composition of mangrove forests across south Florida and Everglades National Park. Future climate change scenarios using these models suggest 
that damage associated with strong storms will likely result in future mangrove forests of smaller stature and that shifts in species composition to stands dominated by red mangrove are likely.

\section{Net Loss of Coastal Habitat}

The ability to predict landward movement of coastal marsh caused by sea-level rise depends on knowledge of the current vegetation distribution and the relationship to topography.

A model based on elevation measurements recorded from different locations in St. Marks NWR was used to analyze the topography and track the process and pattern of coastal inundation for given sea-level rise projections (Fig. 4). All three sea-level rise projections adopted by the Intergovernmental Panel on Climate Change indicate that major portions of the coastal zone would be permanently flooded, bringing about a movement of vegetation community types and loss in total area and proportion of some habitats. The model suggests that a large area of land will be quickly converted from coastal salt- and freshwater marsh to open water on the scale of marsh loss experienced in south Louisiana. There will be some shift of emergent marsh into forested zones as wetlands extend inland, but a net loss of marsh habitat will occur. Site geography and the slope of the land in St. Marks refuge will present an effective barrier to the establishment and growth of some plant communities because of lack of suitable habitat conditions. The landform in this area increases sharply in slope from the sea inland, effectively squeezing area available for forest and marsh.

\section{Conclusions}

The research of USGS scientists and their collaborators reveals both the scale and scope of potential global change impacts on plant communities of low-lying coastal areas. While there remain many uncertainties regarding regional and local responses to changes in climate, current studies of plants and landforms of the U.S. southeastern coastal zone provide strong evidence of the effects of sealevel rise and tropical storms. In the southeastern coastal plain, USGS scientists have documented trends in the changing dynamics of plant communities, loss of coastal wetlands, and erosion of coastal habitats. Future research should provide a more thorough understanding of wetland response to sea-level rise and other consequences of long-term environmental change.

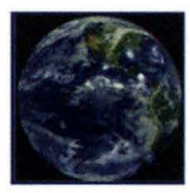

For more information, contact

Glenn Guntenspergen Beth Vairin

or

Virginia R. Burkett

U.S. Geological Survey

National Wetlands Research Center

700 Cajundome Blvd

Lafayette, LA 70506

318-266-8500

beth_vairin@usgs.gov

http://www.nwre.gov

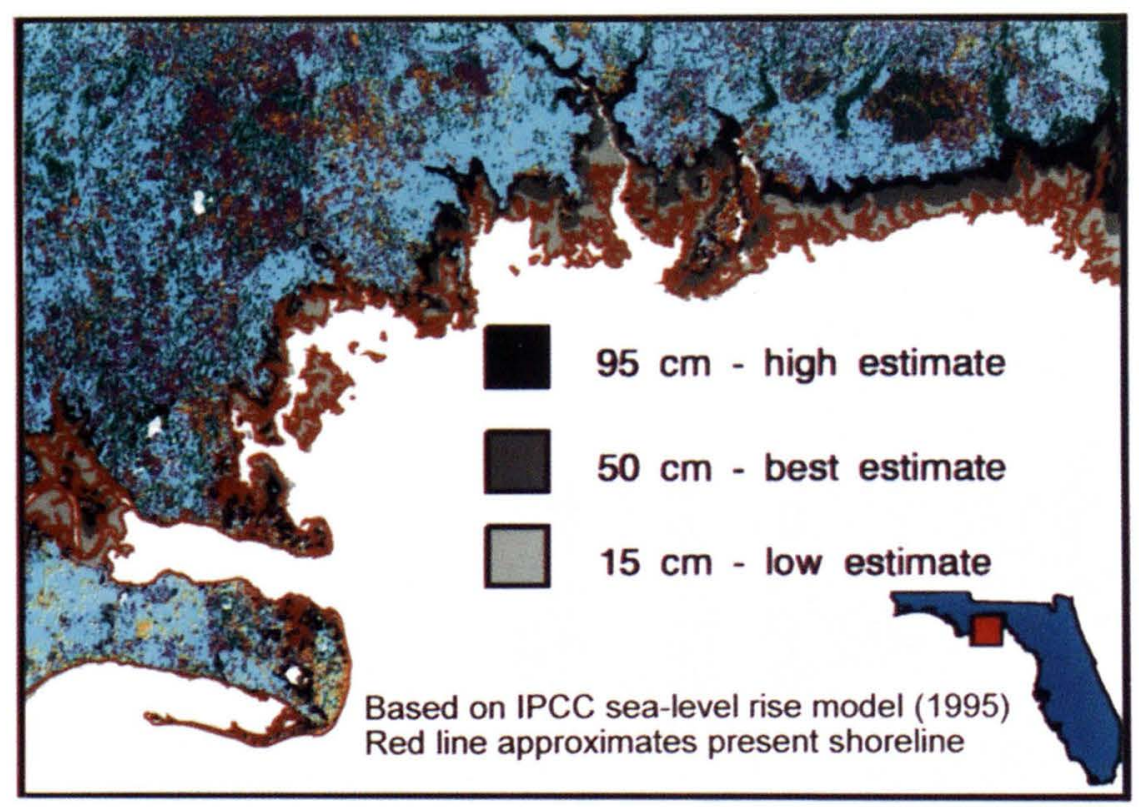

Fig. 4. Predicted shoreline changes by 2100 showing coastal inundation of the St. Marks National Wildlife Refuge area, Florida, for low, mid (best), and high projections of sea-level rise.

\section{Cooperators:}

Rice University

Louisiana State University

Duke University

Clemson University

University of Southwestern

Louisiana

University of Georgia

The College of William and Mary

Louisiana Universities Marine Consortium

East Carolina University

Lamont-Doherty

Geological Observatory

Tall timbers Research

Station 